\section{P164 VALUE OF FATIGUE: PATIENTS VS. PHYSICIANS - TIME TRADE-OFF APPROACH}

Christina Düsing, Matthias Schneider, Gamal Chehab. Policlinic and Hiller Research Unit of Rheumatology, UKD, Heinrich-Heine-University, Duesseldorf, Germany

\subsection{6/lupus-2020-eurolupus.206}

Introduction Fatigue is a common symptom in SLE patients and often held responsible for their reduced quality of life. With this survey, we wanted to examine the degree of suffering in SLE patients with fatigue and determine, whether they would trade in years in order to live without fatigue or if they would trade in fatigue for other disease manifestations (skin, joints or kidney).

Methods Our survey took place during a meeting with patients from the German SLE self-help community on World Lupus Day, May 10th 2019 in Duesseldorf/Germany. Using Edivote $^{\circledR}$, an anonymous audience response system, we asked patients: if they had been questioned by their treating physicians about fatigue (1:always, 2:sometimes, 3:never), how

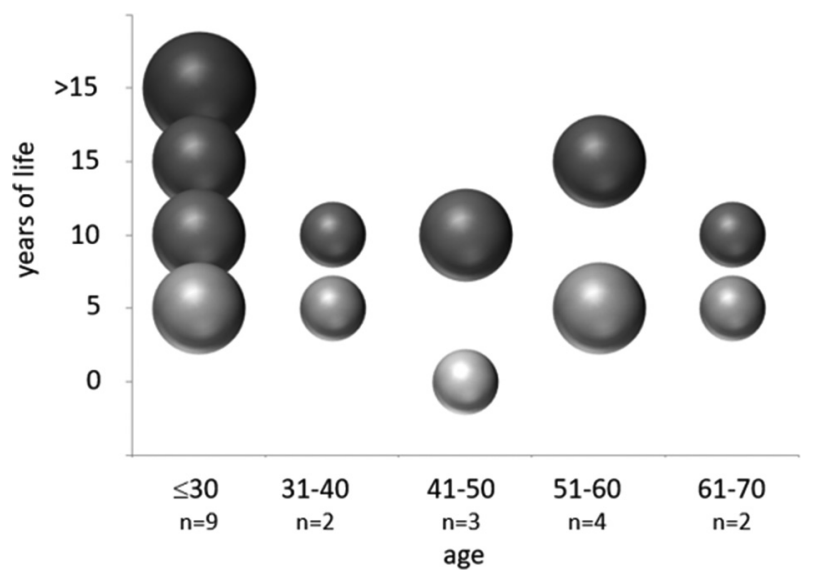

Abstract P164 Figure 1 Results from our time trade-off survey, sorted by patients' age; $n=20$, absolute numbers; (Size of circles represents 1 patient [small] 2 patients [medium] and 3 patients [large]) many years of life they would sacrifice in order to live without fatigue $(0,5,10,15,>15$ years, respectively) and if they would trade in fatigue for another disease manifestation (skin, joints or kidney).

Results 26 patients $(96.2 \%$ female) took part in our survey. Most patients were $\leq 50$ years old $(61.5 \%)$ with a disease duration of $>5$ years $(81.0 \%)$. Six patients were regularly asked about fatigue, four patients were sometimes asked and eight patients had never been asked about fatigue. The results from the time trade-off question are shown in figure 1. Five patients were willing to trade in fatigue for a skin manifestation (consistent redness on exposed skin); one patient wanted to trade in fatigue for a kidney manifestation (50\% reduction of kidney function, edema and fluid restriction).

Conclusion In our cohort, $42 \%$ of responding patients had never been asked about fatigue. To our surprise, almost all patients were willing to trade in $\geq 5$ years for a life without fatigue. This result underlines patients' degree of suffering and should raise more awareness for SLE patients living with fatigue. Our results clearly indicate the discordant assessment of the importance of fatigue by patients and physicians. These findings with respect to time trade-off should be validated in a larger cohort.

\section{P165 PATIENTS WITH SYSTEMIC LUPUS ERYTHEMATOSUS AND LYMPHOMA AT A TERTIARY HOSPITAL}

María Galindo, Maria Martin, Aimara García, Minerva Montalvo. Hospital 12 de Octubre Madrid, Spain

\subsection{6/lupus-2020-eurolupus.207}

Background Evidence of an increased risk to develop haematological malignancy, especially non-Hodgkin's lymphoma (NHL) in autoimmune diseases, has been gathered since the 1970s. In the last decade studies from SLE cohorts have consistently shown a markedly increased risk of NHL.

Objectives To analyze clinical and disease characteristics in SLE patients who developed a lymphoma during follow-up, as

\begin{tabular}{|c|c|c|c|c|c|c|}
\hline n & Manifestations & Haematological & Immunological & Steroid $^{\mathrm{a}}$ & Antimalarials & Immunosuppressant \\
\hline 1 & $\begin{array}{l}\text { Rash, photosensitivity, arthritis, pleuritis, } \\
\text { pericarditis }\end{array}$ & Leucopenia & $\begin{array}{l}\text { ANA, DNA, SS-A, low C, LA, } \\
\text { Anticardiolipin antibodies (IgG) }\end{array}$ & Yes & No & Azathioprine (AZA) \\
\hline 2 & Arthritis & Haemolytic anaemia & ANA, Sm, SS-A & No & Yes & No \\
\hline 3 & $\begin{array}{l}\text { Rash, photosensitivity, discoid, oral ulcers, } \\
\text { pericarditis, headache }\end{array}$ & Lymphopenia & ANA, RNP & Yes & $\begin{array}{l}\text { Previous to } \\
\text { lymphoma }\end{array}$ & No \\
\hline 4 & Rash, arthritis, epilepsia, fever, adenopathies & Leucopenia lymphopenia & ANA, DNA, Sm, low C, LA & Yes & Yes & $\begin{array}{l}\text { Mycophenolate (MMF) } \\
\text { (previous AZA) }\end{array}$ \\
\hline 5 & $\begin{array}{l}\text { Discoide, photosensitivity, fever, splenomegaly, } \\
\text { hemophagocytic syndrome }\end{array}$ & $\begin{array}{l}\text { Leucolymphopenia } \\
\text { thrombocytopenia }\end{array}$ & ANA & Yes & Previous & $\begin{array}{l}\text { Previous } \\
\text { cyclophosphamide }\end{array}$ \\
\hline 6 & Oral ulcers, splenomegaly & $\begin{array}{l}\text { Platelets }<20000 \text {, haemolytic } \\
\text { anaemia }\end{array}$ & $\begin{array}{l}\text { ANA, SS-A, low C, LA, Anticardiolipin } \\
\text { antibodies (IgM) }\end{array}$ & Yes & No & Rituximab \\
\hline 7 & Rash, photosensitivity & Leucopenia lymphopenia & $\begin{array}{l}\text { ANA, SS-A, SS-B, low C, LA, } \\
\text { Anticardiolipin antibodies (IgM/G) }\end{array}$ & Previous & Yes & No \\
\hline 8 & $\begin{array}{l}\text { Arthritis, epilepsia, CNS vasculitis, stroke, } \\
\text { pleuritis, pericarditis }\end{array}$ & Thrombocytopenia & Anticardiolipin antibodies (lgG) & Yes & Previous & No \\
\hline 9 & Arthritis, stroke, glomerulonephritis & $\begin{array}{l}\text { Haemolytic anaemia, } \\
\text { thrombocytopenia lymphopenia }\end{array}$ & $\begin{array}{l}\text { ANA, DNA, RNP, SS-A, low C, } \\
\text { Anticardiolipin antibodies (IgG) }\end{array}$ & Yes & Previous & Mycophenolate (MMF) \\
\hline
\end{tabular}

